\title{
Transformasi Wilayah Kabupaten Demak Sebagai Kawasan Pinggiran di dalam Proses Metropolitanisasi Semarang
}

\author{
Spatial Transformation of Demak Regency as the Peri-urban Area in \\ Metropolitanization of Semarang
}

\author{
Siti Nur Alifya ${ }^{1}$ \\ Departemen Perencanaan Wilayah dan Kota, Fakultas Teknik \\ Universitas Diponegoro, Semarang, Indonesia
}

\section{Fadjar Hari Mardiansjah}

Departemen Perencanaan Wilayah dan Kota, Fakultas Teknik Universitas Diponegoro, Semarang, Indonesia

Artikel Masuk : 14 September 2020

Artikel Diterima : 8 April 2021

Tersedia Online : 31 Agustus 2021

\begin{abstract}
Abstrak: Ketersediaan jaringan jalan regional, sebagai infrastruktur pengakomodasian kegiatan serta interaksi antar-wilayah, membagi kecamatan-kecamatan di Kabupaten Demak menjadi beberapa kawasan dengan dinamika proses perkembangan dan transformasi yang berbeda. Pemahaman proses transformasi yang terjadi pada masing-masing kawasan tersebut penting untuk diketahui. Penelitian ini bertujuan untuk mengkaji proses transformasi wilayah pada masing-masing kawasan di Kabupaten Demak dan mengetahui kawasan mana saja yang mengalami transformasi atau perkembangan secara cepat. Transformasi penggunaan atau pemanfaatan lahan dianalisis menggunakan teknik Maximum Likelihood dan Calculate Area pada Arcgis. Transformasi kependudukan dianalisis menggunakan teknik analisis deskriptif kuantitatif dan transformasi ekonomi akan dianalisis menggunakan teknik analisis Loqation Quotient (LQ) dan deskriptif kuantitatif. Hasil penelitian ini menunjukkan bahwa Kawasan Barat-Selatan dan Kawasan Barat-Utara, yang berlokasi bersebelahan dengan Kota Metropolitan Semarang dan dihubungkan dengan jaringan jalan regional, memiliki perkembangan atau transformasi yang lebih besar daripada kawasan yang lokasinya jauh dari Kota Metropolitan Semarang. Terdapat beberapa faktor yang menyebabkan kawasankawasan di Kabupaten Demak berkembang secara cepat seperti kedekatan dengan Kota Metropolitan Semarang, ketersediaan jaringan jalan di kawasan tersebut, serta aktivitas internal kawasannya. Diketahui pula bahwa penyusunan RTRW Kabupaten Demak belum memperhatikan perkembangan atau dinamika yang terjadi pada beberapa kawasan tersebut. Selain itu, terdapat beberapa kawasan yang membutuhkan perhatian dari pemerintah Kabupaten Demak, yaitu kawasan timur-utara dan kawasan tengah, yang perkembangannya masih di bawah arahan RTRW sehingga perkembangannya perlu didorong karena
\end{abstract}

\footnotetext{
${ }^{1}$ Korespondensi Penulis: Departemen Perencanaan Wilayah dan Kota, Fakultas Teknik Universitas Diponegoro, Semarang, Indonesia

Email: nuralifyadiysi@students.undip.ac.id
} 
penyusunan RTRW yang belum memperhatikan perkembangan atau dinamika di masingmasing kawasan tersebut.

Kata Kunci: Kabupaten Demak; peri-urban; spasial; transformasi wilayah

\begin{abstract}
The availability of regional road network, as an infrastructure for accommodating activities and interregional interactions has made the areas of Demak Regency divided into several areas according to the differences in dynamics of their development process. All areas in Demak Regency have transformed gradually with some different level dynamics in each area. It is important to understand the transformation process in the district including in each area. This study aims to examine the regional transformation process in each area in Demak Regency and find out which areas are undergoing rapid transformation or development than others. Land use transformation is analyzed by using the Maximum Likelihood and Calculate Area analysis techniques in Arcgis. Population transformation analyzed using quantitative descriptive analysis techniques and economic transformation analyzed using $L Q$ analysis techniques and descriptive analysis. The result shows that the south-west and north-west areas, which are bordering to the Metropolitan City of Semarang and traversed by regional road network tend to have a more dynamic transformation than other areas that are more far from the city. There are some factors that bring some areas of Demak Regency to develop rapidly, such as the proximity to the metropolitan city, the availability of regional road networks, and the development of activities in the area. It is also found that the formulation of the RTRW for Demak Regency has not taken the different dynamics of development of areas in the district into account. So, there are some areas that need more attention from the Government of Demak Regency, like the east-north and central areas whose development is still under the level directed in the RTRW, so that their development needs to be encouraged. as a result of the formulation that has not paid attention different dynamics in each areas.
\end{abstract}

Keywords: Demak Regency; peri-urban; regional transformation; spatial

\title{
Pendahuluan
}

Ketersediaan lahan di kota yang bersifat tetap yang berbanding terbalik dengan jumlah penduduk kota yang semakin meningkat menyebabkan perkembangan kota menyebar hingga ke luar daerah perkotaan (Dewi et al., 2016). Perkembangan kota tersebut berdampak pada berkembangnya kawasan yang memiliki ciri khas perkotaan di daerah pinggiran kota (peri-urban). Perkembangan yang terjadi di kawasan-kawasan dan kota-kota kecil seringkali dianggap tidak penting, namun dalam kenyataannya masa depan perkotaan tidak hanya terjadi di kota-kota besar melainkan juga di kota kecil dan termasuk di kawasan-kawasan perkotaan di pinggiran (Mardiansjah et al., 2018). Sementara itu, Cohen (2006) berpendapat bahwa meskipun kota-kota tersebut relatif kecil, namun dapat memberikan kontribusi positif bagi daerah sekitarnya, merangsang ekonomi pedesaan dan spesialisasi fungsi, sebagai pusat identitas dan pelayanan baru, serta menyeimbangkan perkembangan pesat dari kawasan metropolitan. Hal ini menjadi penting karena kota-kota kecil di kawasan pinggiran kota seringkali bertransformasi menjadi kawasan peri-urban dan terus berkembang menjadi kawasan perkotaan (Kurnianingsih \& Rudiarto, 2014). Di Indonesia perkembangan kota-kota kecil utamanya paling banyak terjadi di Pulau Jawa.

Perkembangan kawasan peri-urban di kota-kota di Pulau Jawa telah terjadi dan tersebar di hampir seluruh kota termasuk di Kota Semarang. Perkembangan ini juga terjadi ke wilayah Kabupaten Demak sebagai salah satu bagian dari kawasan pinggiran Metropolitan Semarang. Kabupaten Demak merupakan salah satu kawasan yang menjadi tempat perkembangan kawasan perkotaan dan kawasan peri-urban dalam proses metropolitanisasi Semarang. Namun, perkembangan di Kabupaten Demak tidak terjadi di seluruh wilayah secara bersamaan. Perkembangan terjadi di beberapa titik awal dan baru 
mulai menjalar ke wilayah lain dalam beberapa waktu selanjutnya. Setiawan \& Rudiarto (2016) menjelaskan bahwa hal ini disebabkan oleh empat faktor, yaitu adanya konsentrasi penduduk dengan segala aktivitasnya, aksesibilitas terhadap pusat kegiatan dan pusat kota, jaringan jalan dan sarana transportasi, serta orbitasi yaitu jarak yang menghubungkan suatu wilayah dengan pusat-pusat pelayanan yang lebih tinggi. Kurniawan (2016) juga menjelaskan bahwa proses transformasi wilayah yang terjadi biasanya berawal dari pusat pedesaan yang memiliki koneksi jalan utama yang umumnya menjadi simpul penghubung transportasi antarwilayah. Proses ini kemudian bergerak memanjang linier ke sepanjang koridor jalan tersebut, sehingga memungkinkan terjadinya penyatuan perkembangan kawasan perkotaan dan perdesaan di sepanjang koridor jalannya (Hardati, 2011). Perubahan penggunaan lahan dalam pelaksanaan pembangunan tidak dapat dihindari. Perubahan tersebut terjadi karena dua hal, yaitu adanya keperluan untuk memenuhi kebutuhan penduduk yang semakin meningkat jumlahnya dan yang kedua berkaitan dengan meningkatnya tuntutan akan mutu kehidupan yang lebih baik (Fahmi et al., 2014).

Perkembangan kawasan Kabupaten Demak ditandai dengan perkembangan kepadatan penduduk di kecamatan tersebut dalam kurun waktu 20 tahun terakhir. Pada tahun 2000, Kabupaten Demak memiliki kepadatan penduduk rata-rata $1.092 \mathrm{jiwa} / \mathrm{km}^{2}$ dan mengalami peningkatan pada tahun 2020 menjadi 1.291 jiwa $/ \mathrm{km}^{2}$. Mardiansjah et al. (2019) menjelaskan bahwa pola pembangunan kawasan/kota juga dapat dilihat dari perubahan atau transformasi demografis dan populasi perkotaan di suatu kawasan, yang juga dipengaruhi oleh adanya reklasifikasi wilayah dari kawasan yang terkategori sebagai perdesaan di suatu masa menjadi terkategori perkotaan pada masa selanjutnya. Perubahan status kawasan ini juga mengubah status penduduknya menjadi penduduk perkotaan, yang turut mempengaruhi jumlah penduduk perkotaan secara keseluruhan. Berdasarkan data dari BPN wilayah Jawa Tengah, pada tahun 2009 terjadi alih fungsi lahan di Kabupaten Demak sebesar 2.317.873 $\mathrm{m}^{2}$ (Dewi et al., 2016). Alih fungsi lahan yang paling banyak terjadi di Kecamatan Mranggen, hal ini disebabkan adanya pertumbuhan daerah permukiman baru (Perumnas Pucanggading Semarang) di daerah Batursari serta pengembangan industri di sekitar koridor Jalan Semarang-Mranggen. Hal ini sejalan dengan teori bahwa transformasi wilayah dapat membentuk pola seiring dengan pengembangan jaringan jalan. Keberadaan jaringan jalan tersebut akan seiring pula dengan pengembangan kawasan perumahan dan permukiman. Proses transformasi tersebut berjalan secara bertahap pada kawasan hunian yang dominan. Ketersediaan jaringan jalan sebagai infrastruktur pengakomodasi kegiatan serta interaksi antarkecamatan di Kabupaten Demak menyebabkan kecamatan-kecamatan di Kabupaten Demak terbagi menjadi enam kawasan yaitu Kawasan Barat-Selatan, Kawasan Barat-Utara, Kawasan Tengah, Kawasan Timur-Selatan, Kawasan Timur-Utara, dan Kawasan Utara. Masing-masing kawasan mengalami proses transformasi dan perkembangan yang berbeda. Adapun proses transformasi wilayah yang terjadi di Kabupaten Demak tentunya bukan hanya secara fisik, tetapi juga perubahan dari segi ekonomi dan budaya penduduk yang berhubungan dengan struktur produksi, mata pencaharian, dan adat-istiadat penduduk. Melalui proses perkembangannya tersebut, dapat diketahui bahwa setiap kawasan di Kabupaten Demak memiliki proses transformasi yang bertahap. Hal ini dapat dilihat dari sifat kawasan periurban yang masih berkembang dan adanya kemungkinan transformasi tersebut masih terus berlanjut.

Beberapa penelitian mengenai transformasi wilayah telah dilakukan, salah satunya yang dilakukan Giyarsih (2010), dalam penelitiannya didapatkan bahwa transformasi wilayah yang tinggi mengelompok di desa-desa yang dekat dengan jaringan jalan sedangkan desa-desa yang jauh dari jaringan jalan perkembangannya relatif rendah. Hal ini sejalan dengan penelitian yang dilakukan oleh Kurnianingsih \& Rudiarto (2014), pada transformasi wilayah di Kecamatan Kartasura bahwa transformasi di kawasan tersebut 


\section{Transformasi Wilayah Kabupaten Demak Sebagai Kawasan Pinggiran ...}

sangat dipengaruhi oleh perkembangan urban area dan aksesibilitas, yaitu di daerah yang dekat dengan Kota Surakarta dan Yogyakarta dan kawasan yang berlokasi di sekitar jalan utama. Adanya aksesibilitas ini memudahkan masyarakat dalam melakukan pergerakan untuk menunjang aktivitas. Hal ini dikarenakan aksesibilitas yang mudah di dalam suatu wilayah akan memudahkan interaksi yang terjadi di antara satu kawasan dengan kawasan yang lain (Farida, 2013). Penelitian ini merupakan pelengkap dari penelitian-penelitian sebelumnya tentang transformasi wilayah di kawasan peri-urban. Penelitian ini mendiskusikan fenomena transformasi wilayah di Kabupaten Demak dengan berfokus pada perubahan intensitas penggunaan lahan serta aktivitas di dalamnya yang tadinya bersifat kedesaan menjadi kekotaan diikuti dengan perubahan stuktur ekonomi masyarakatnya. Penelitian ini juga membuktikan bahwa kawasan-kawasan yang memiliki kedekatan (proximity) dengan pusat-pusat aktivitas di Kota Semarang, terutama yang memiliki ketersediaan jaringan jalan regional yang menjamin aksesibilitas kawasannya, menjadi kawasan yang mengalami transformasi secara cepat. Selain itu, penelitian ini juga memperlihatkan faktor-faktor yang mempengaruhi perkembangan tersebut. Oleh karena itu, model penelitian seperti ini juga dapat dijadikan sebagai salah satu analisis penting sebelum melakukan evaluasi terhadap RTRW, terutama pada wilayah-wilayah pinggiran dari suatu kawasan metropolitan seperti Metropolitan Semarang ini. Penelitian ini bertujuan untuk mengkaji proses transformasi wilayah pada masing-masing kawasan di Kabupaten Demak dan mengetahui kawasan mana saja yang mengalami transformasi atau perkembangan secara cepat.

\section{Metode Penelitian}

Metode penelitian yang dilakukan pada penelitian ini yaitu penelitian kuantitatif dengan kebutuhan pengumpulan data dilakukan melalui survei sekunder (kajian literatur dan telaah dokumen, terutama RTRW Kabupaten Demak). Adapun metode kuantitatif yang digunakan dalam penelitian ini adalah analisis maximum likelihood menggunakan Geographic Information System (GIS) untuk mendapatkan hasil yang diinginkan. Selain itu, analisis dilakukan dengan menggunakan metode analisis deskriptif kuantitatif pada data time series dengan menggunakan data klasifikasi desa (desa-desa perkotaan) pada tahun 1990, 2000, 2010 dan 2020, beserta data penduduk maupun ekonomi yang dihasilkan oleh Badan Pusat Statistik (BPS) dari proses pelaksanaan Sensus Penduduk Nasional.

Selain melakukan analisis kewilayahan yang dibantu dengan GIS, baik terhadap pergeseran dan perkembangan penggunaan lahan dan kawasan-kawasan perkotaan yang dijelaskan di atas, penelitian ini juga melakukan analisis pergeseran terhadap perubahan kondisi perekonomian wilayah. Hal ini dilakukan baik dalam bentuk analisis pergeseran yang berbasis kepada PDRB maupun analisis pergeseran dalam perkembangan aktivitas ekonomi wilayah, terutama kepada pergeseran aktivitas pekerjaan penduduk yang berbasiskan pada kegiatan pertanian dan nonpertanian. Analisis yang terakhir ini dilakukan dengan menggunakan data sekunder ini juga dilakukan dalam bentuk analisis kewilayahan. Untuk dapat memahami metode penelitian yang dilakukan dapat dilihat pada Gambar 1.

\section{Hasil dan Pembahasan}

\section{Kabupaten Demak Sebagai Kawasan Pinggiran Metropolitan Semarang}

Kabupaten Demak merupakan kabupaten yang bersebelahan dengan Kota Semarang, dengan luas wilayah sebesar 897,43 $\mathrm{km}^{2}$. Kabupaten ini terdiri dari 14 kecamatan, 243 desa, dan 6 kelurahan. Jumlah penduduk kabupaten sebanyak 1.158.772 jiwa tahun 2020, dengan kepadatan 1.291,21 jiwa/ $\mathrm{km}^{2}$. Letak kabupaten yang berada di sebelah timur Kota 
Semarang, tepatnya di sebelah Kecamatan Pedurungan dan Kecamatan Genuk, memberi lokasi yang strategis karena Kabupaten Demak menjadi lokasi perambatan aktivitas Kota Semarang, khususnya yang berada di Kecamatan Pedurungan dan Genuk. Selain dipengaruhi faktor kedekatan (proximity), perambatan aktivitas perkotaan ke wilayah Kabupaten Demak juga diperkuat oleh adanya jaringan jalan utama yang menghubungkan Kota Semarang ke Kabupaten Demak yaitu Jalan Majapahit yang berada di Kecamatan Pedurungan, dan Jalan Kaligawe yang berada di Kecamatan Genuk.

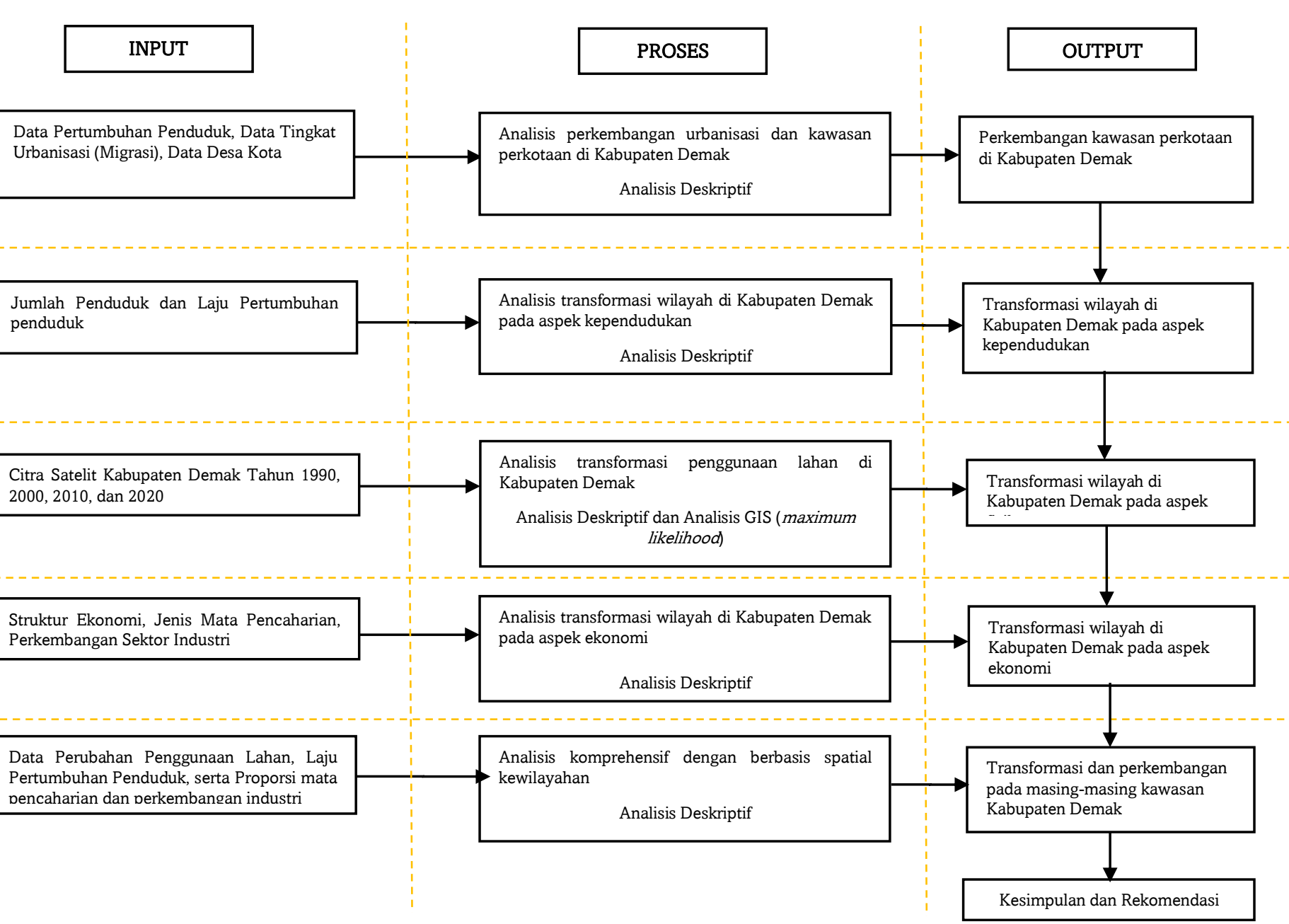

\section{Gambar 1. Kerangka Analisis Penelitian}

Penggunaan lahan di Kabupaten Demak tahun 2020 masih didominasi oleh sawah irigasi sebesar $37 \%$ dan lahan permukiman dan bangunan sebesar 16\%. Namun, penggunaan lahan permukiman dan bangunan meningkat cukup pesat bila dibandingkan dengan tahun 2010 yang masih hanya sebesar $12 \%$. Alih fungsi lahan menjadi lahan permukiman paling banyak terjadi di Kecamatan Mranggen, yang berlokasi di sebelah Kecamatan Pedurungan, Kota Semarang, dengan adanya pertumbuhan daerah permukiman baru di Kawasan Batursari serta perkembangan industri di sekitar koridor jalan Semarang-Mranggen.

Penduduk Kabupaten Demak juga mengalami peningkatan setiap tahunnya dalam 10 tahun terakhir. Kondisi ini juga disebabkan oleh faktor kedekatan jarak kabupaten ini dari 


\section{Transformasi Wilayah Kabupaten Demak Sebagai Kawasan Pinggiran ...}

Kota Semarang. Hal ini sesuai dengan pendapat Shi et al. (2012), perkembangan kota berdampak pada munculnya kawasan yang memiliki ciri khas perkotaan di daerah pinggiran kota yang juga ikut berkembang. Perkembangan dan ekspansi kota ini yang kemudian memicu perubahan kawasan dari wilayah rural ke wilayah peri-urban (Ravetz et al., 2013). Pertumbuhan penduduk yang paling besar terjadi di Kecamatan Mranggen, yang berkembang sebagai kawasan permukiman baru sebagai perluasan dari permukiman yang berkembang di Kecamatan Pedurungan, Semarang. Berkembangnya perumahanperumahan baru di Kawasan Mranggen juga merupakan implikasi dari semakin berkembangnya aktivitas di Kota Semarang yang turut melakukan ekspansi aktivitas ke kawasan di sekitarnya, termasuk menyebabkan berkembangnya kawasan permukiman di pinggiran kota khususnya di Kecamatan Mranggen. Hal ini sesuai dengan pendapat Aguilar (2008) bahwa ekspansi kota menyebabkan terjadinya perubahan penggunaan lahan di kawasan peri-urban atau daerah pinggiran, utamanya peningkatan intensitas penggunaan lahan untuk permukiman dan diiringi peningkatan jumlah penduduk.

\section{Analisis Perkembangan Urbanisasi dan Kawasan Perkotaan di Kabupaten Demak}

Seperti yang dapat dilihat pada Gambar 2 adalah peta perkembangan kawasan perkotaan di Kabupaten Demak dari tahun 1990 ke tahun-tahun berikutnya, yaitu tahun 2000, 2010, dan 2017, analisis perkembangan urbanisasi dan kawasan perkotaan di Kabupaten Demak dilakukan dengan mengamati perkembangan jumlah dan lokasi dari desa-desa perkotaan yang ada di Kabupaten Demak, dengan turut memperhitungkan pertumbuhan penduduk di desa-desa perkotaan tersebut. Analisis ini dilakukan dengan analisis spasial yang memetakan desa-desa perkotaan tersebut di setiap waktu untuk beberapa titik waktu, sehingga bisa dipahami perkembangan kawasan perkotaan yang direpresentasikan oleh perkembangan desa-desa perkotaan tersebut dari waktu ke waktu.

Data yang digunakan adalah data hasil pengklasifikasian desa yang dilakukan BPS terhadap seluruh desa dan kelurahan di Kabuaten Demak pada tahun 1990, 2000, 2010, dan 2017. Gambar 2 memperlihatkan bahwa perkembangan kawasan perkotaan di Kabupaten Demak tidak terkonsentrasi pada suatu kawasan tertentu saja, melainkan tersebar pada beberapa kawasan. Kawasan Tengah, Kawasan Barat-Selatan dan Kawasan Barat-Utara merupakan kawasan-kawasan yang menjadi pusat konsentrasi perkotaan yang direpresentasikan oleh perkembangan desa-desa perkotaan tersebut.

Perkembangan di Kawasan Tengah (Demak-Bonang-Wonosalam) tidak terlepas dari keberadaan Kecamatan Demak yang berada di kawasan ini sebagai ibukota kabupaten yang juga merupakan pusat aktivitas perdagangan dan aktivitas pelayanan utama dari Kabupaten Demak. Perkembangan di kawasan ini juga dipengaruhi oleh keberadaan jalan regional utama yang menghubungkan Kota Semarang ke arah timur yang melalui kawasan dan Kecamatan Demak ini. Perkembangan aktivitas-aktivitas tersebut membawa pengaruh terhadap perubahan karakteristik desa-desa yang terdapat di kecamatan ini, sehingga berubah dan terklasifikasi menjadi desa-desa perkotaan lebih cepat dibandingkan dengan banyak desa di kecamatan-kecamatan lainnya.

Kawasan Barat-Selatan (Mranggen-Karangawen) yang berbatasan langsung dengan Kota Semarang, khususnya Kecamatan Pedurungan (dengan fungsi sebagai kawasan perkembangan permukiman di Kota Semarang), serta dihubungkan secara langsung oleh Jalan Majapahit ke kawasan pusat Kota Semarang, memiliki dorongan yang kuat terhadap proses pertumbuhan penduduk sebagai akibat banyak berkembangnya perumahan di kawasan ini. Hal ini mengakibatkan proses urbanisasi dan perkembangan perkotaan yang terjadi di kawasan ini juga lebih cepat daripada yang terjadi di kawasan-kawasan lain. Sementara itu, di Kawasan Barat-Utara (Sayung-Karangtengah-Guntur), yang juga berbatasan langsung dengan Kota Semarang, juga mendapat pengaruh perkembangan dari 
Kota Semarang. Kawasan ini berbatasan dengan Kecamatan Genuk yang berfungsi sebagai kawasan pengembangan kegiatan industri di Kota Semarang. Akibatnya, perkembangan di kawasan ini juga sangat dipengaruhi oleh perkembangan kegiatan industri, serta perkembangan kawasan perumahan yang menyertainya.
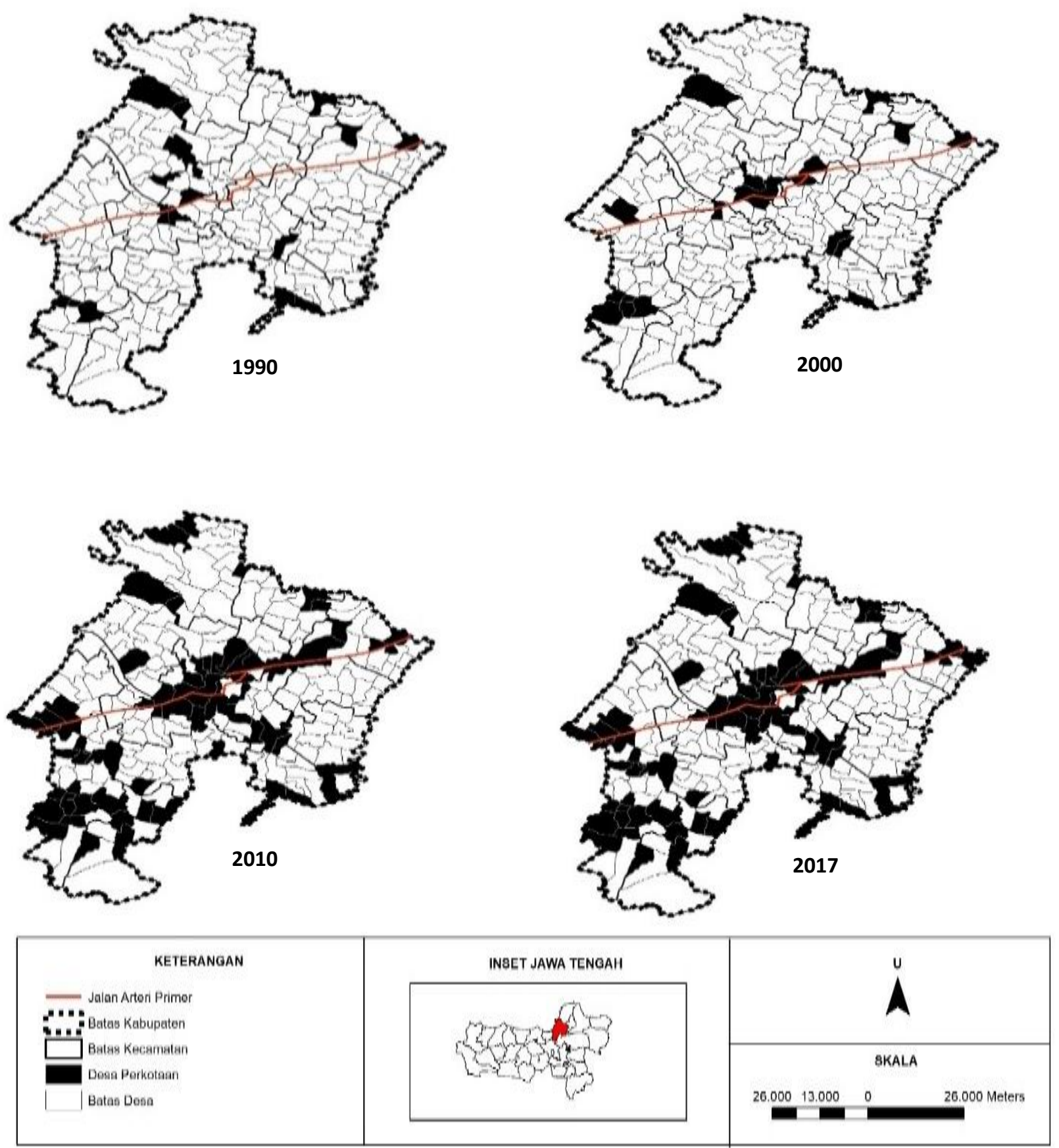

Gambar 2. Peta Perkembangan Desa-desa Perkotaan menjadi Kawasan Perkotaan

Perkembangan desa perkotaan di Kabupaten Demak pun terus berkembang dan meluas dari waktu ke waktu. Secara spasial dapat dilihat bahwa perkembangan kawasan perkotaan di Kawasan Barat-Selatan terjadi secara merambat dari Kota Semarang. 


\section{Transformasi Wilayah Kabupaten Demak Sebagai Kawasan Pinggiran ...}

Perkembangan kawasan perkotaan di kawasan tersebut, selanjutnya juga merambat ke wilayah kecamatan lain di dalam kawasan tersebut. Kondisi serupa juga terjadi pada Kawasan Tengah dan Kawasan Barat-Utara yang juga sangat dipengaruhi oleh pertumbuhan dan perkembangan aktivitas di Kota Semarang. Namun, perkembangan kawasan perkotaan yang terjadi di ketiga kawasan tersebut lebih masif terutama pada tahun 2010 hingga 2017. Hal ini yang kemudian berdampak pada perluasan kawasan perkotaan dan transformasi wilayah di Kabupaten Demak.

\section{Analisis Perubahan dan Perkembangan Penduduk Perkotaan}

Dalam konteks perkembangan jumlah penduduk perkotaan, Kabupaten Demak juga merupakan tempat yang menampung limpahan penduduk perkotaan dari Kota Semarang. Faktor-faktor kedekatan dan konektivitas yang kuat ini menyebabkan pertumbuhan penduduk perkotaan yang terjadi di Kabupaten Demak cukup cepat, terutama pada Kawasan Baraat-Selatan, Kawasan Barat-Utara dan Kawasan Tengah. Salah satu hal yang menarik adalah pertumbuhan penduduk perkotaan di Kabupaten Demak ini tidak terjadi secara merata pada seluruh kawasan yang ada, yaitu pertumbuhan penduduk perkotaan di Kawasan Timur-Utara, Kawasan Timur-Selatan, dan Kawasan Utara terjadi secara lebih lambat daripada yang terjadi pada ketiga Kawasan Barat Dan Tengah (lihat Tabel 1). Kondisi ini mengindikasikan besarnya pengaruh Kota Semarangyang berada di sebelah barat Kabupaten Demak terhadap pertumbuhan penduduk di kabupaten ini.

Tabel 1. Pertumbuhan Penduduk Perkotaan di Kabupaten Demak Tahun 1990-2017

\begin{tabular}{|c|c|c|c|c|c|c|c|c|}
\hline \multirow{2}{*}{ Nama Daerah } & \multicolumn{3}{|c|}{$\begin{array}{c}\text { Jumlah Penduduk Perkotaan } \\
\text { (Jiwa) }\end{array}$} & \multicolumn{2}{|c|}{ Proporsi (\%) } & \multicolumn{3}{|c|}{$\begin{array}{c}\text { Laju Pertumbuhan } \\
(\%)\end{array}$} \\
\hline & 1990 & 2000 & 2010 & 2017 & 1990 & 2017 & $\begin{array}{l}1990- \\
2000\end{array}$ & $\begin{array}{l}2000- \\
2017\end{array}$ \\
\hline $\begin{array}{l}\text { Kawasan Barat-Selatan } \\
\text { (Mranggen-Karangawen) }\end{array}$ & 17.393 & 31.594 & 141.208 & 164.941 & 21,6 & 37,4 & 6,15 & 10,21 \\
\hline $\begin{array}{l}\text { Kawasan Barat-Utara } \\
\text { (Sayung-Karangtengah- } \\
\text { Guntur) }\end{array}$ & 7.508 & 9.792 & 73.881 & 80.183 & 9,3 & 18,2 & 2,69 & 13,17 \\
\hline $\begin{array}{l}\text { Kawasan Tengah (Demak- } \\
\text { Bonang-Wonosalam) }\end{array}$ & 32.886 & 40.885 & 103.563 & 112.052 & 40,8 & 25,4 & 2,20 & 6,11 \\
\hline $\begin{array}{l}\text { Kawasan Timur-Selatan } \\
\text { (Dempet-Kebonagung) }\end{array}$ & 3.312 & 4.886 & 26.665 & 28.362 & 4,1 & 6,4 & 4 & 10,90 \\
\hline $\begin{array}{l}\text { Kawasan Timur-Utara } \\
\text { (Gajah-Karanganyar) }\end{array}$ & 4.978 & 5.507 & 23.034 & 27.502 & 6,2 & 6,2 & 1 & 9,92 \\
\hline $\begin{array}{l}\text { Kawasan Utara (Mijen- } \\
\text { Wedung) }\end{array}$ & 14.623 & 13.598 & 29.860 & 28.403 & 18,1 & 6,4 & 1 & 4,43 \\
\hline Kabupaten Demak & 80.700 & 106.262 & 398.211 & 441.443 & 100 & 100 & 2,79 & 8,74 \\
\hline
\end{tabular}

Pada tahun 2000, Kabupaten Demak memiliki jumlah penduduk sebesar 980.218 jiwa dengan 106.262 jiwa penduduk yang tinggal di kawasan perkotaan. Hal ini memperlihatkan bahwa sekitar 10,8\% penduduk Kabupaten Demak merupakan penduduk perkotaan yang tinggal tersebar di kawasan-kawasan perkotaan yang ada seperti yang diperlihatkan pada Tabel 1. Sensus penduduk tahun 2010, memperlihatkan bahwa Kabupaten Demak memiliki penduduk sekitar 1.086.443 jiwa. Dibandingkan dengan jumlah penduduk perkotaan pada Tabel 1, maka dapat diketahui bahwa proporsi penduduk perkotaan di Kabupaten Demak telah mencapai sekitar 37\% pada tahun 2010. Sedangkan pada tahun 2017 jumlah penduduk Kabupaten Demak yang tinggal di kawasan perkotaan yaitu sekitar 441.443 jiwa 
dari 1.140.675 jiwa penduduk total. Dengan demikian, Kabupaten Demak telah memiliki proporsi sekitar 38,7\% dari penduduknya tinggal di kawasan perkotaan pada tahun 2017 .

Pesatnya perkembangan tingkat urbanisasi atau proporsi penduduk perkotaan terhadap penduduk totalnya tersebut memperlihatkan pesatnya laju urbanisasi yang terjadi di Kabupaten Demak.Dalam kurun waktu 17 tahun terakhir persentase jumlah penduduk yang tinggal di kawasan perkotaan Kabupten Demak terus meningkat dari 10,8\% menjadi 38,7\%. Namun, sebagian besar pertumbuhan urbanisasi di kabupaten ini cenderung terkonsentrasi pada Kawasan Barat dan Kawasan Tengah yang masih mendapat pengaruh dari Kota Semarang. Kondisi ini serupa dengan penelitian yang dilakukan Wahyudi et al. (2018) dengan menggunakan studi kasus Kawasan Jabodetabek yang memperlihatkan bahwa pertumbuhan dan perkembangan kawasan perkotaan tidak terjadi secara merata di seluruh tempat, melainkan cenderung terkonsentrasi pada kawasan-kawasan utama tertentu, terutama kawasan-kawasan yang memperoleh pengaruh dari pusat-pusat konsentrasi utama di wilayahnya.

\section{Analisis Perubahan Penggunaan Lahan dan Perkembangan Intensitas Penggunaan Lahan}

Menurut Smailes (1955), transformasi wilayah secara fisik dapat diidentifikasi melalui perubahan pemanfaatan lahan, karakteristik bangunan dan karakteristik sirkulasi dimana hal tersebut terjadi di Kabupaten Demak. Sejalan dengan hal tersebut, Suharyadi (2010) berpendapat bahwa transformasi dapat dilihat dari perubahan lahan nonterbangun kepada lahan terbangun. Transformasi pemanfaatan lahan dalam penelitian ini dilakukan dengan menganalisis perubahan bentuk pemanfaatan dari lahan nonterbangun menjadi terbangun dengan analisis yang menggunakan Sistem Informasi Geografis (SIG) yang hasilnya dapat diamati pada Gambar 3. Analisis ini dilakukan dengan menggunakan data citra satelit Kabupaten Demak pada tahun 1990, 2000, 2010, dan 2020 yang kemudian diolah menggunakan Arcgis dengan analisis maximum likelihood. Gambar 3 memperlihatkan kecenderungan terjadinya peningkatan lahan terbangun di Kabupaten Demak, bahwa peningkatan terutama terjadi dari tahun 2000 ke tahun 2010 hingga ke tahun 2020.

Hasil analisis memperlihatkan bahwa perubahan lahan terbangun paling besar terjadi pada periode tahun 2000 ke 2010, dengan peningkatan lahan sebesar 11.952 hektar. Peningkatan lahan terbesar berikutnya terjadi pada periode 2010 ke 2020, dengan peningkatan sebesar 2.925 hektar. Adapun seluruh peningkatan lahan terbangun antara tahun 1990 hingga 2020 adalah sebesar 14.977 hektar.

Ketiga kawasan yang berada dekat dengan Kota Semarang merupakan kawasankawasan dengan peningkatan lahan terbangun terbesar. Dari ketiga kawasan ini, Kawasan Barat-Selatan (Mranggen-Karangawen) merupakan kawasan yang paling banyak mengalami peningkatan lahan terbangun dengan luas peningkatan seluruhnya antara tahun 1990 hingga 2020 mencapai 3.859 hektar. Kawasan Barat-Utara (Sayung-KarangtengahGuntur) menempati posisi berikutnya dengan peningkatan seluas 3.329 hektar, dan Kawasan Tengah (Demak-Bonang-Wonosalam) berada pada posisi ketiga dengan luas peningkatan sebesar 3.219 hektar. Adapun peningkatan lahan terbangun pada ketiga kawasan lainnya, yaitu Kawasan Timur-Selatan (Dempet-KebonAgung), Kawasan TimurUtara (Gajah-Karanganyar), dan Kawasan Utara (Mijen-Wedung) terjadi dengan luasan jauh lebih kecil daripada yang terjadi pada ketiga Kawasan Barat dan Tengah. 

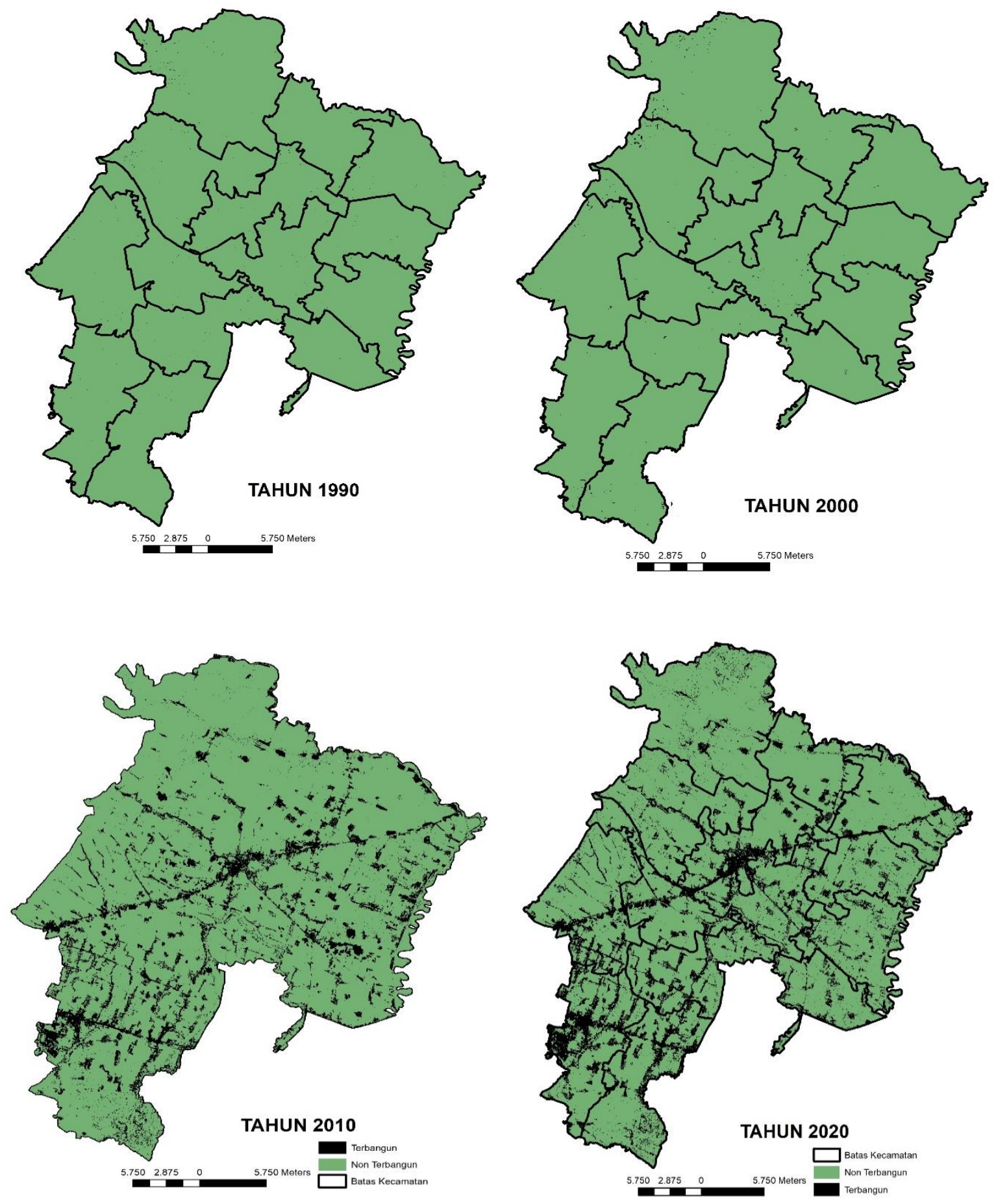

\section{Gambar 3. Peta Pemanfaatan Lahan Kabupaten Demak Tahun 1990, 2000, 2010, dan 2020}

Hasil analisis memperlihatkan bahwa perubahan lahan terbangun paling besar terjadi pada periode tahun 2000 ke 2010, dengan peningkatan lahan sebesar 11.952 hektar. Peningkatan lahan terbesar berikutnya terjadi pada periode 2010 ke 2020, dengan 
peningkatan sebesar 2.925 hektar. Adapun seluruh peningkatan lahan terbangun antara tahun 1990 hingga 2020 adalah sebesar 14.977 hektar.

Ketiga kawasan yang berada dekat dengan Kota Semarang merupakan kawasankawasan dengan peningkatan lahan terbangun terbesar. Dari ketiga kawasan ini, Kawasan Barat-Selatan (Mranggen-Karangawen) merupakan kawasan yang paling banyak mengalami peningkatan lahan terbangun dengan luas peningkatan seluruhnya antara tahun 1990 hingga 2020 mencapai 3.859 hektar. Kawasan Barat-Utara (Sayung-KarangtengahGuntur) menempati posisi berikutnya dengan peningkatan seluas 3.329 hektar, dan Kawasan Tengah (Demak-Bonang-Wonosalam) berada pada posisi ketiga dengan luas peningkatan sebesar 3.219 hektar. Adapun peningkatan lahan terbangun pada ketiga kawasan lainnya, yaitu Kawasan Timur-Selatan (Dempet-KebonAgung), Kawasan TimurUtara (Gajah-Karanganyar), dan Kawasan Utara (Mijen-Wedung) terjadi dengan luasan jauh lebih kecil daripada yang terjadi pada ketiga Kawasan Barat dan Tengah.

Salah satu hal yang menarik adalah bahwa peningkatan lahan terbangun di seluruh kawasan-kawasan ini terjadi pada periode yang sama yaitu periode antara tahun 2000 hingga 2010. Hal yang menarik lain adalah seperti yang diperlihatkan pada Gambar 3, peningkatan lahan terbangun cenderung terkonsentrasi pada jalur koridor jaringan jalan yang ada, yaitu koridor Jalan Raya Semarang-Demak hingga Demak-Kudus yang merupakan jaringan jalan nasional yang menghubungkan Kota Semarang ke Surabaya di arah timur, dan sepanjang koridor Jalan Raya Mranggen yang merupakan jaringan jalan provinsi yang menghubungkan Kota Semarang ke Purwodadi, ibukota Kabupaten Grobogan.

Kondisi yang terjadi di wilayah Kabupaten Demak ini serupa dengan hasil yang disampaikan oleh Wahyudi et al. (2018) yang memperlihatkan bahwa pertumbuhan di Kawasan Jabodetabek cenderung terkonsentrasi pada kawasan-kawasan tertentu yang terpengaruh olrh keberadaan pusat-pusat utama yang ada, dan juga serupa dengan hasil penelitian dari Kurnianingsih \& Rudiarto (2014) dan Giyarsih (2010) yang memperlihatkan kawasan yang mengalami pertumbuhan dan transformasi wilayah cenderung terutama terjadi pada kawasan-kawasan yang memiliki aksesibilitas jalan yang baik, terutama jalan regional utama.

\section{Analisis Perubahan dan Pergeseran Aktivitas Ekonomi Perkotaan}

\section{Analisis PDRB}

Analisis PDRB dilakukan untuk melihat perubahan dan pergeseran struktur ekonomi wilayah Kabupaten Demak, dengan menganalisis pergeseran dan perkembangan sektor basis dan nonbasis. Analisis ini dilakukan dengan menggunakan analisis LQ atau Location Quotient, dengan membandingkan sektor-sektor ekonomi wilayah Kabupaten Demak tahun 1990, 2000, 2010, dan 2019 terhadap wilayah Kedungsepur (Kota Semarang, Kota Salatiga, Kabupaten Demak, Kabupaten Semarang, Kabupaten Kendal, dan Kabupaten Grobogan) untuk tahun yang sama. Analisis Location Quotient (LQ) merupakan analisis yang digunakan untuk melihat sektor-sektor yang mampu menjadi sektor-sektor basis, yaitu sektor-sektor yang mampu turut melayani kebutuhan dari wilayah yang lebih besar daripada kebutuhan yang ada di wilayahnya sendiri. Dengan demikian, selain memperlihatkan perkembangan kemampuan sektor spesialisasi di suatu wilayah yaitu Kabupaten Demak dalam penelitian ini, perkembangan suatu sektor dari sektor nonbasis menjadi sektor basis dari waktu ke waktu di wilayah tersebut juga memperlihatkan perkembangan penguatan sektor-sektor tersebut di dalam peranannya pada perekonomian wilayah yang lebih luas. 
120 Transformasi Wilayah Kabupaten Demak Sebagai Kawasan Pinggiran ...

Tabel 2. Analisis LQ Kabupaten Demak

\begin{tabular}{|c|c|c|c|c|c|}
\hline \multirow{2}{*}{ Klasifikasi Sektor } & \multirow{2}{*}{ Sektor } & \multicolumn{4}{|c|}{ Lq } \\
\hline & & 1990 & 2000 & 2010 & 2019 \\
\hline \multirow[t]{2}{*}{ Primer } & Pertanian & Basis $(2,42)$ & Basis $(3,22)$ & Basis $(2,66)$ & Basis $(2,49)$ \\
\hline & Pertambangan Dan Penggalian & Basis $(1,65)$ & Nonbasis & Basis $(1,43)$ & Basis $(1,01)$ \\
\hline \multirow[t]{3}{*}{ Sekunder } & Industri Pengolahan & Nonbasis & Nonbasis & Nonbasis & Basis $(1,00)$ \\
\hline & Listrik, Gas, Dan Air Bersih & Nonbasis & Nonbasis & Nonbasis & Nonbasis \\
\hline & Bangunan & Nonbasis & Nonbasis & Nonbasis & Nonbasis \\
\hline \multirow[t]{4}{*}{ Tersier } & Perdagangan, Hotel, Dan Restoran & Nonbasis & Nonbasis & Basis $(1,00)$ & Basis $(1,07)$ \\
\hline & Pengangkutan Dan Komunikasi & Nonbasis & Nonbasis & Nonbasis & Nonbasis \\
\hline & Keuangan, Persewaan, Dan Jasa Perusahaan & Nonbasis & Nonbasis & Nonbasis & Nonbasis \\
\hline & Jasa-Jasa & Basis $(1,03)$ & Basis $(1,01)$ & Basis $(1,31)$ & Basis $(1,34)$ \\
\hline
\end{tabular}

Hasil Analisis LQ yang dilakukan pada Tabel 2 memperlihatkan bahwa Sektor Perdagangan, Hotel dan Restoran dan Sektor Industri Pengolahan dari Kabupaten Demak mengalami penguatan peran sejak tahun 2010 (Sektor Perdagangan, Hotel dan Restoran) dan tahun 2019 (Sektor Industri Pengolahan). Jadi, walaupun sektor pertanian kabupaten ini tetap menjadi sebagai sektor basis dalam kurun waktu 30 tahun terakhir, Kabupaten Demak juga mengalami peningkatan peran dalam konstelasi perekonomian wilayah Kedungsepur, untuk juga menjadi tempat penting bagi kegiatan sektor perdagangan, hotel dan restoran, dan juga Sektor Industri Pengolahan. Kondisi ini mengindikasikan telah dimulainya pergeseran atau transformasi ekonomi dan peran dari Kabupaten Demak dari sebelumnya yang lebih bertumpu kepada peran-peran di sektor primer (Sektor Pertanian dan Sektor Pertambangan) untuk kemudian juga kepada Sektor Perdagangan, Hotel dan Restoran dan Sektor Industri. Seperti yang dijelaskan oleh Liang \& Yang (2019), proses penguatan peran ekonomi yang dipengaruhi oleh pertumbuhan ekonomi dari sektor-sektor perdagangan, hotel dan restoran serta industri pengolahan ini mendorong proses urbanisasi dan transformasi di Kabupaten Demak.

\section{Analisis Non PDRB}

Analisis ekonomi non PDRB dilakukan dengan menganalisis pergeseran jumlah penduduk Kabupaten Demak yang bekerja di sektor pertanian dan nonpertanian dalam jangka panjang, yaitu dari tahun 1990, ke tahun 2000, 2010 dan 2019. Analisis yang juga dilakukan untuk setiap kawasan yang dirumuskam di Kabupaten Demak ini dilakukan untuk melihat pergesseran tumpuan pekerjaan dari penduduknya dari waktu ke waktu.

Hasil analisis pada Tabel 3 memperlihatkan bahwa jumlah pekerja di sektor pertanian mengalami penurunan, walau masih sempat mengalami peningkatan di antara tahun 1990 ke 2000. Sebaliknya, jumlah pekerja di sektor nonpertanian terus mengalami peningkatan dari waktu ke waktu, dengan jumlah peningkatan yang sangat massif terjadi pada periode antara tahun 2000 hingga 2010. Kondisi ini memperlihatkan bahwa pekerjaan di sektor pertanian bukan lagi merupakan pekerjaan utama dari penduduk Kabupaten Demak, yang semakin beralih kepada pekerjaan di luar sektor pertanian.

Ketiga kawasan yang berlokasi paling dekat dengan Kota Semarang, yaitu Kawasan Barat-Selatan (Mranggen-Karangawen), Kawasan Barat-Utara (Sayung-KarangtengahGuntur) dan Kawasan Tengah (Demak-Bonang-Wonosalam) merupakan kawasan-kawasan yang paling banyak mengalami peningkatan penduduk yang bekerja pada sektor-sektor nonpertanian. Kawasan Tengah yang merupakan kawasan konsentrasi perkotaan tertuamerupakan kawasan yang mengalami peningkatan terbesar. Kawasan Barat-Utara yang merupakan kawasan pengembangan kegiatan industri menempati posisi berikutnya, 
dan Kawasan Barat-Selatan yang merupakan tempat pengembangan kawasan perumahan menempati posisi ketiga.

Tabel 3. Mata Pencaharian Penduduk Kawasan Perkotaan

\begin{tabular}{|c|c|c|c|c|c|c|c|c|}
\hline \multirow[t]{2}{*}{ Nama Daerah } & \multicolumn{5}{|c|}{$\begin{array}{c}\text { Penduduk Bermata Pencaharian Sektor } \\
\text { Pertanian (Jiwa) }\end{array}$} & \multicolumn{3}{|c|}{$\begin{array}{l}\text { Penduduk Bermata } \\
\text { Pencaharian Sektor } \\
\text { Nonpertanian (Jiwa) }\end{array}$} \\
\hline & 1990 & 2000 & 2010 & 2010 & 1990 & 2000 & 010 & 019 \\
\hline (Mrar & 50.564 & 48.324 & 35.793 & 36.854 & 49.030 & 54.312 & 118.204 & 117.30 \\
\hline $\begin{array}{l}\text { Kawasan Barat-Utara } \\
\text { (Sayung-Karangtengah- } \\
\text { Guntur) }\end{array}$ & 50.869 & 3 & 5 & 8 & 47 & 19 & 118 & 140 \\
\hline $\begin{array}{l}\text { Kawasan Tengah (Demak- } \\
\text { Bonang-Wonosalam) }\end{array}$ & 44.102 & 55.116 & 30.719 & 37.777 & 74.860 & 57.777 & 129.174 & 191.038 \\
\hline Kawasan Timur-Selatan & 34.771 & 32.317 & 17.316 & 19.725 & 43.548 & 19.771 & 29.280 & $45.8^{\circ}$ \\
\hline $\begin{array}{l}\text { Kawasan Timur-Utara } \\
\text { (Gajah-Karanganyar) }\end{array}$ & 4 & 4 & 22 & 9 & 78 & 210 & 52 & 68.047 \\
\hline $\begin{array}{l}\text { Kawasan Utara (Mijen- } \\
\text { Wedung) }\end{array}$ & 37.620 & 35.297 & 17.740 & 17.361 & 58.546 & 47.436 & 81.512 & 86.301 \\
\hline Jumlah & 259.368 & 264.161 & 155.497 & 170.284 & 324.109 & 251.025 & 546.505 & 649.370 \\
\hline
\end{tabular}

\section{Analisis Komprehensif (Analisis Transformasi Wilayah Kabupaten Demak)}

Analisis komprehensif dilakukan untuk memadukan hasil-hasil analisis yang dilakukan secara parsial sebelumnya, untuk memahami variasi proses transformasi wilayah yang terjadi di Kabupaten Demak dari tahun 1990 hingga saat ini. Ringkasan dari analisis ini dapat dilihat pada Gambar 4.

Hasil analisis memperlihatkan bahwa sebagai kawasan pinggiran dari Metropolitan Semarang, proses transformasi wilayah di Kabupaten Demak sangat dipengaruhi oleh perkembangan yang terjadi di wilayah Kota Semarang. Kondisi ini sangat tampak dari kawasan-kawasan yang mengalami proses transformasi yang cepat (berkembang) dapat diklasifikasi terdiri dari dua jenis kawasan (lihat Gambar 4), yaitu kawasan yang secara historis telah menjadi Kawasan konsentrasi dan pusat pelayanan, dan Kawasan yang memiliki potensi untuk berkembang, seperti yang dijelaskan oleh Mardiansjah et al. (2021). Kawasan Pusat yang terdiri dari Kecamatan Demak, Bonang dan Wonosalam merupakan kawasan yang secara historis menjadi kawasan konsentrasi dan pusat pelayanan, sebagai akibat dari kondisi bahwa Kecamatan Demak merupakan lokasi ibukota dan pusat konsentrasi pelayanan di Kabupaten Demak sejak ratusan tahun yang lalu. Sementara itu, Kawasan Barat-Selatan yang terdiri dari Kecamatan Mranggen dan Karangawen dan Kawasan Barat-Utara yang terdiri dari Kecamatan Sayung, Karang Tengah dan Guntur, merupakan kawasan-kawasan yang mendapat potensi pembangunan karena faktor kedekatan (proximity) dan ketersediaan jaringan jalan regional yang menghubungkannya ke pusat Kota Semarang. Argumen ini juga diperkuat oleh kondisi bahwa Kawasan BaratSelatan lah yang memiliki perubahan/transformasi wilayah yang paling dinamis, walaupun kawasan ini lebih merupakan kawasan yang baru berkembang, seperti Kawasan BaratUtara. 


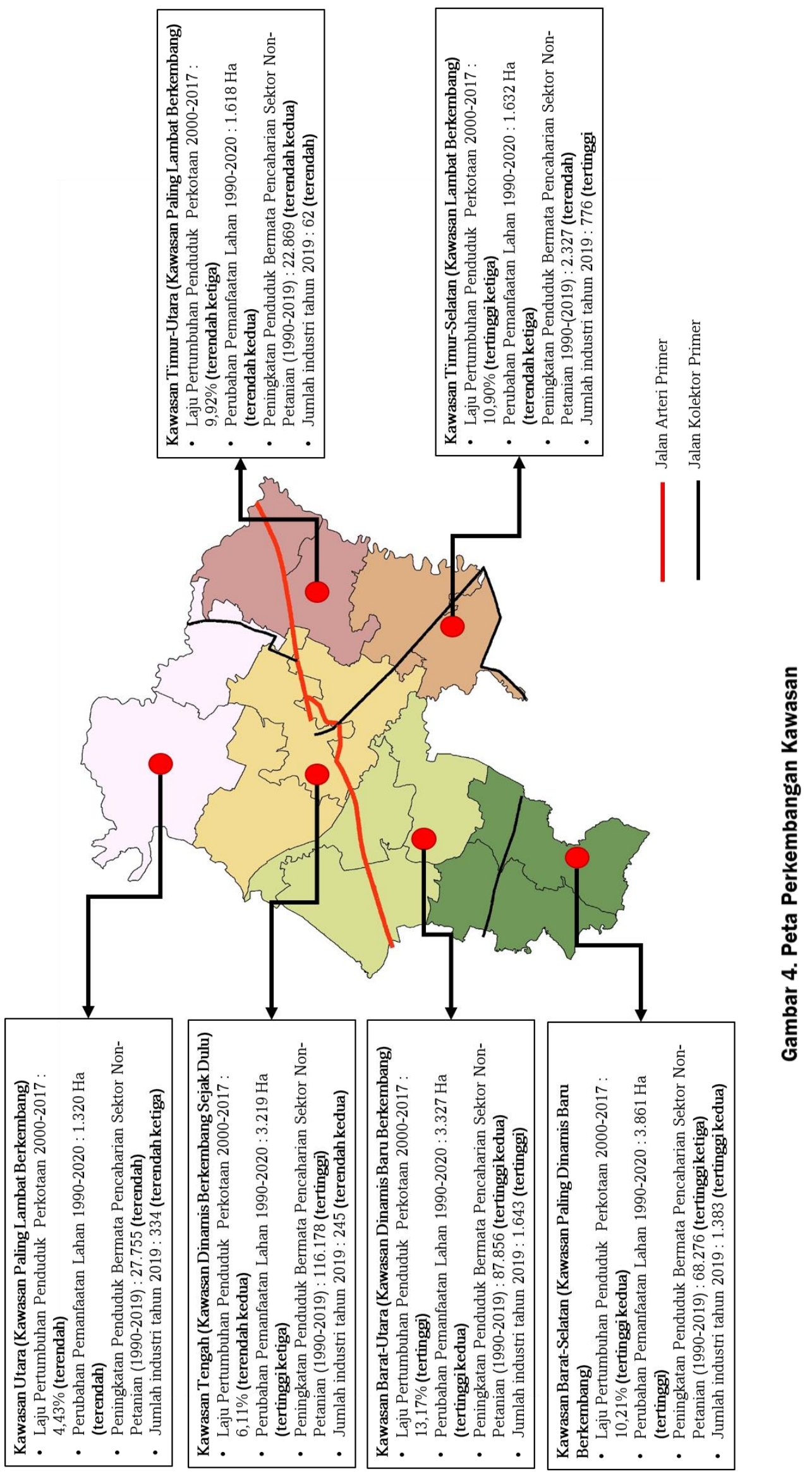


Pada dasarnya, transformasi yang terjadi pada Kawasan Barat-Selatan lebih didorong oleh perkembangan kegiatan perumahan dan permukiman yang terjadi di dalamnya. Selain karena faktor kedekatan dan ketersediaan jalan regional, perkembangan ini didukung oleh situasi dimana kawasan ini berlokasi bersebelahan dengan Kawasan Pedurungan, Kota Semarang yang juga berfungsi sebagai kawasan perkembangan kawasan perumahan dan permukiman. Fungsi perumahan dan permukiman yang didukung oleh perkembangan industri, berkembang di kawasan ini membuat tingkat pertumbuhan penduduk perkotaan sangat tinggi (tertinggi kedua) dan pertumbuhan lahan terbangun di kawasan ini terjadi sangat tinggi (tertinggi), dan jauh lebih tinggi bila dibandingkan kepada yang terjadi di kawasan-kawasan lainnya (lihat Gambar 4). Suatu hal yang bisa dipahami karena perumahan merupakan aktivitas perkotaan yang sangat besar melakukan kosumsi lahan.

Sedangkan Kawasan Barat-Utara yang bersebelahan dengan Kawasan Genuk Semarang yang menjadi kawasan perkembangan kegiatan industri, juga berkembang menjadi tempat utama dari perkembangan kegiatan industri di Kabupaten Demak. Perkembangan ini juga menjadikan Kawasan Barat-Utara ini menjadi kawasan yang dinamis perkembangannya, dengan jumlah perkembangan kegiatan industri tertinggi, laju pertumbuhan penduduk perkotaan yang tertinggi, dan jumlah peningkatan pekerja nonpertanian yang juga sangat tinggi. Namun, karena kawasan ini cenderung berkembang untuk kegiatan industri dan ditambah oleh kondisi banjir rob yang sering terjadi di dalam kawasan ini (Subardjo \& Ario, 2015), maka kegiatan perumahan kurang berkembang di kawasan ini. Sehingga, walaupun kawasan ini memiliki tingkat pertumbuhan industri tertinggi sehingga mendorong terjadinya pertumbuhan ekonomi dan urbanisasi di kawasan tersebut seperti yang disampaikan oleh Liang \& Yang (2019) bahwa urbanisasi terjadi sebagai akibat pertumbuhan ekonomi kota yang mendorong terjadinya permintaan tenaga kerja, seperti diperlihatkan oleh terjadinya peningkatan penduduk bermata pencaharian nonpertanian yang lebih tinggi di kawasan ini daripada di Kawasan Barat-Selatan, namun, peningkatan lahan terbangunnya juga lebih rendah daripada Kawasan Barat-Selatan.

Transformasi wilayah yang terjadi di Kawasan Pusat dipengaruhi oleh sejarah kawasan ini sebagai tempat berlokasinya Kecamatan Demak yang menjadi ibukota kabupaten yang juga menjadi kawasan konsentrasi perkotaan dan pusat pelayanan utama kabupaten sejak masa lalu. Faktor historis ini mendorong Kawasan Pusat tetap berkembang sebagai Kawasan yang tumbuh dan bertransformasi secara dinamis, dengan memiliki pertambahan penduduk yang bekerja di luar sektor pertanian yang tertinggi, dan peningkatan lahan terbangun yang tertinggi, walaupun jumlah perkembangan aktivitas industri kawasan ini termasuk yang terendah (lihat Gambar 4). Kawasan Pusat, terutama di Kecamatan Demak, berkembang menjadi kawasan pelayanan, baik pelayanan ekonomi dengan berkembangnya faslitas-fasilitas perdagangan dan komersial lainnya maupun pelayanan sosial dengan berkembangnya fasilitas pendidikan, kesehatan, serta rekreasi. Mirip seperti hasil penelitian yang dilakukan oleh Kurniawan (2016), perkembangan dan transformasi yang terjadi di kawasan ini berawal dari pusat aktivitas yang telah berkembang sejak masa lalu yang terdapat di Kecamatan Demak, yang berkembang melebar terutama memanjang linier mengikuti koridor jaringan jalan nasional yang ada. Dengan demikian, bisa dikatakan bahwa faktor historis dan faktor keberadaan jalan regional merupakan faktor-faktor yang mendorong proses transformasi yang terjadi di kawasan ini.

Sementara itu, ketiga Kawasan Timur-Selatan, Timur-Utara dan Kawasan Utara merupakan Kawasan-kawasan yang lambat berkembang atau bertransformasi. Kawasankawasan ini juga memiliki jumlah dan pertumbuhan desa-desa perkotaan yang sangat sedikit bila dibandingkan dengan yang dimiliki oleh kawasan-kawasan sebelumnya. Aktivitas ekonomi wilayah yang berkembang di ketiga kawasan ini masih didominasi oleh aktivitas pertanian, dengan adanya penetrasi aktivitas perkotaan secara sporadis di 


\section{Transformasi Wilayah Kabupaten Demak Sebagai Kawasan Pinggiran ...}

beberapa lokasi. Dari ketiga kawasan ini, Kawasan Timur-Selatan yang memiliki tingkat perkembangan yang paling baik, sehingga hanya terkategori sebagai Kawasan Lambat Berkembang, sedangkan kedua Kawasan lainnya terkategori sebagai Kawasan Paling Lambat Berkembang (Lihat Gambar 4). Kawasan Timur-Selatan ini memiliki jumlah kegiatan industri yang cukup tinggi, yaitu tertinggi ketiga, dari seluruh jumlah industri di setiap kawasan, sehingga memiliki laju pertumbuhan perkotaan yang juga cukup tinggi, yaitu tertinggi ketiga. Namun, pertumbuhan penduduk perkotaan yang terjadi lebih diakibatkan oleh terjadinya reklasifikasi desa dari desa-desa nonperkotaan menjadi desadesa perkotaan, sebagaimana jumlah desa perkotaan di kawasan ini bertambah dari 2 desa di tahun 1990 menjadi tujuh desa di tahun 2017. Akibatnya, pertambahan penduduk yang bekerja di luar sektor pertaniannya pun terendah, sehingga belum mampu meningkatkan perubahan dan/atau transformasi wilayah yang terjadi di kawasan ini.

Perkembangan aktivitas industri yang terjadi di Kawasan Timur-Selatan diperkirakan terjadi karena adanya jaringan jalan regional yang menghubungkan kawasan ini ke Kota Semarang melalui Kecamatan Mranggen (Kawasan Barat-Selatan), yang dikombinasi oleh kedekatan lokasi kawasan ini kepada Kecamatan Mranggen, yang bisa dikatakan sebagai kawasan perkembangan utama di Kabupaten Demak yang juga menjadi Kawasan perluasan permukiman dari Kota Semarang. Sementara itu, Kawasan Timur-Utara yang juga dilintasi oleh jalan regional dari/menuju ke Semarang tidak memiliki perkembangan kegiatan industri yang baik, bahkan terendah di antara seluruh Kawasan (lihat Gambar 4), karena kawasan ini tidak berada dekat dari Kawasan perkembangan utama yang ada di Kabupaten Demak. Kondisi ini memperllihatkan bahwa faktor kedekatan (proximity) merupakan faktor yang lebih penting daripada faktor ketersediaan jaringan jalan regional.

\section{Kesimpulan}

Penelitian ini memperlihatkan bahwa urbanisasi dan transformasi merupakan proses yang saling berkaitan, seperti yang dikemukakan oleh Soh (2012), yang terkombinasi dari proses-proses demografi, spasial, dan sosial-ekonomi yang memperlihatkan proses pertumbuhan perkotaan dan mengubah kawasan-kawasan menjadi bersifat kekotaan. Analisis yang dilakukan pada Kabupaten Demak yang merupakan kawasan pinggiran dari Kota Semarang juga memperlihatkan proses serupa seperti yang dikemukakan oleh Pawan (2016), dimana proses ini juga mengakibatkan pergeseran masyarakat dari karakteristik masyarakat perdesaan menjadi masyarakat yang lebih bersifat perkotaan dengan dipicu oleh perkembangan sosial, ekonomi, dan juga spasial.

Pada transormasi wilayah yang terjadi pada Kabupaten Demak memperlihatkan proses metropolitanisasi yang meluas, dengan pola perluasan kawasan-kawasan aktivitas perkotaan yang berasal dari kota inti, yaitu dari Kota Semarang, sambil melakukan penguatan terhadap kawasan pusat konsentrasi penduduk, aktivitas dan pelayanan yang telah ada sebelumnya. Proses transformasi ini berkembang dari proses-proses demografi, ekonomi dan spasial yang multidimensi dan saling terkait, dan mengubah pola pemanfaatan lahan dari lahan nonterbangun, seperti lahan pertanian, menjadi lahan terbangun, terutama pada kawasan-kawasan tertentu, yang menurut Mardiansjah et al. (2021) memenuhi dua kriteria utama, yaitu faktor sejarah perkembangan yang telah ada sebelumnya dan/atau faktor potensi perkembangan yang ada. Faktor-faktor ini selarah dengan pendapat Setiawan \& Rudiarto (2016) yang menyebutkan konsentrasi penduduk yang telah ada, keberadaan jalan regional, aksesibilitas ke pusat kota, dan orbitase atau jarak kawasan kepada pusat pelayanan utama yang lebih tinggi.

Pada kawasan pinggiran metropolitan seperti Kabupaten Demak, penelitian ini memberikan gambaran bahwa kombinasi dari faktor kedekatan (proximity) dan ketersediaan jaringan jalan regional lebih mampu memberikan pengaruh pertumbuhan dan 
transformasi wilayah kepada perubahan dan pertumbbuhan yang terjadi. Faktor-faktor tersebut juga menjadi karakteristik khusus dari transformasi wilayah yang terjadi di Kabupaten Demak dimana keberadaan Kota Semarang, termasuk perkembangan aktivitas pada kecamatan-kecamatan pinggirannya yaitu Kecamatan Pedurungan dan Kecamatan Genuk, sangat berpengaruh terhadap transformasi yang terjadi di Kabupaten Demak, terutama pada kawasan-kawasan yang bersebelahan dengan Kota Semarang. Bahkan penelitian ini jga mengindikasikan bahwa kedekatan kepada Kecamatan Mranggen sebagai kawasan pusat pertumbuhan utama di Kabupaten Demak pun mampu memberikan pengaruh pertumbuhan kepada Kawasan Timur-Selatan.

Dengan demikian, seperti yang diikemukakan oleh Fahmi et al. (2014), analisis ini juga memperlihatkan bahwa pertumbuhan penduduk perkotaan juga meningkat dan bergeser secara bertahap dari kota besar ke kawasan-kawasan perkotaan kecil dan berikutnya ke kawasan perkotaan yang lebih kecil lagi. Proses transformasi tersebut turut memberikan kontribusi kekuatan pertumbuhan yang berasal dari kota dan/atau kawasan perkotaan yang berada di sekitarnya. Oleh karena itu, seperti pendapat Cohen (2006), kondisi ini menunjukkan pentingnya pengelolaan pertumbuhan kawasan-kawasan perkotaan kecil, karena kawasan-kawasan tersebut dapat memberikan kontribusi positif dan merangsang pertumbuhan pusat-pusat fungsi dan pelayanan baru, termasuk dalam menyeimbangkan perkembangan metropolitan dan juga menyeimbangkan perkembangan desa-kota, atau bahkan sebaliknya. Pengelolaan yang berkelanjutan dan terintegrasi antara kawasan pusat dan kawasan pinggiran dari kawasan metropolitan sangat penting untuk dilakukan mengingat transformasi yang cepat pada beberapa kawasan di Kabupaten Demak ini juga merupakan suatu pola yang terjadi pada banyak kabupaten di pinggir kotakota besar dan kecil yang ada di Indonesia.

\section{Daftar Pustaka}

Aguilar, A. G. (2008). Peri-urbanization, illegal settlements and environmental impact in Mexico City. Cities, 25, 133-145. doi:10.1016/j.cities.2008.02.003.

Cohen, B. (2006). Urbanization in developing countries: Current trends, future projections, and key challenges for sustainability. Technology in Society, 28(1-2), 63-80. doi:10.1016/j.techsoc.2005.10.005.

Dewi, D. I. K., Rahmatullah, A. R., \& Pangi, P. (2016). Land use change in sub district Mranggen because of residential development. Procedia - Social and Behavioral Sciences, 227, 210-215. doi:10.1016/j.sbspro.2016.06.064.

Fahmi, F. Z., Hudalah, D., Rahayu, P., \& Woltjer, J. (2014). Extended urbanization in small and medium-sized cities: The case of Cirebon, Indonesia. Habitat International, 42, 1-10. doi:10.1016/j.habitatint.2013.10.003.

Farida, U. (2013). Pengaruh aksesibilitas terhadap karakteristik sosial ekonomi masyarakat pedesaan Kecamatan Bumijawa Kabupaten Tegal. Jurnal Wilayah dan Lingkungan, 1(1), 49-66. doi:10.14710/jwl.1.1.49-66.

Giyarsih, S. R. (2010). Pola spasial transformasi wilayah di koridor Yogyakarta-Surakarta. Forum Geografi, 24(1), 28-38. doi:10.23917/forgeo.v24i1.5013.

Hardati, P. (2011). Transformasi wilayah peri urban. kasus di Kabupaten Semarang. Jurnal Geografi, 8(2), 108117. doi:10.15294/jg.v8i2.1661.

Kurnianingsih, N. A., \& Rudiarto, I. (2014). Analisis transformasi wilayah peri-urban pada aspek fisik dan sosial ekonomi (Kecamatan Kartasura). Jurnal Pembangunan Wilayah dan Kota, 19(3), 265-277. doi:10.14710/pwk.v10i3.7784.

Kurniawan, M. F. (2016). Analisis dampak transformasi spasial urban fringe timur Kota Surakarta kaitannya dengan perkembangan kawasan perumahan tahun 2003-2013. Universitas Sebelas Maret.

Liang, W., \& Yang, M. (2019). Urbanization, economic growth, and environmental pollution: Evidance in China. Sustainable Computing: Informatics and System, 21, 1-9. doi:10.1016/j.suscom.2018.11.007. 


\section{Transformasi Wilayah Kabupaten Demak Sebagai Kawasan Pinggiran ...}

Mardiansjah, F. H., Handayani, W., \& Setyono, J. S. (2018). Pertumbuhan penduduk perkotaan dan perkembangan pola distribusinya pada Kawasan Metropolitan Surakarta. Jurnal Wilayah dan Lingkungan, 6(3), 215-233. doi:10.14710/jwl.6.3.215-233.

Mardiansjah, F. H., Sugiri, A., \& Sari, G. P. (2019). Urban population growth and their implication to agricultural land in the process of metropolitanization: The case of Kabupaten Sukoharjo, in Metropolitan Surakarta. IOP Conference Series: Earth and Environmental Science, 328, 1-8. doi:10.1088/1755$1315 / 328 / 1 / 012064$

Mardiansjah, F. H., Rahayu, P., \& Rukmana, D. (2021). New patterns of urbanization in Indonesia: Emergence of non-statutory towns and new extended urban regions. Environment and Urbanization ASIA. 21(1), 11-26. doi:10.1177/0975425321990384.

Pawan, P. (2016). Urbanization and its causes and effects: A review. International Journal of Research and Scientific Innovation, III(IX), 110-112.

Ravetz, J., Fertner, C., \& Nielsen, T. S. (2013). The dynamics of peri-urbanization. In Peri-urban futures: Scenarios and models for land use change in europe ( $\mathrm{pp} 13-44)$.

Setiawan, B., \& Rudiarto, I. (2016). Kajian perubahan penggunaan lahan dan struktur ruang Kota Bima. Jurnal Pembangunan Wilayah dan Kota, 12(2), 154-168. doi:10.14710/pwk.v12i2.12892.

Shi, Y., Sun, X., Zhu, X., Li, Y., \& Mei, L. (2012). Characterizing growth types and analyzing growth density distribution in response to urban growth patterns in peri-urban areas of Lianyungang City. Landscape and Urban Planning, 105(4), 425-433. doi:10.1016/j.landurbplan.2012.01.017.

Smailes, A. E. (1955). Some reflection on the geographical description and analysis of townscapes. Transactions and Papers (Institute of British Geographers), 21, 99-115. doi:10.2307/621275.

Soh, M. B. C. (2012). Crime and urbanization: Revisited Malaysian Case. Procedia - Social and Behavioral Sciences, 42, 291-299. doi:10.1016/j.sbspro.2012.04.193.

Subardjo, P., \& Ario, R. (2015). Genangan banjir pasang pada kawasan pemukiman di Kecamatan Sayung, Kabupaten Demak - Provinsi Jawa Tengah. Jurnal Kelautan Tropis, 18(1), 7-12. doi:10.14710/jkt.v18i1.506.

Suharyadi. (2010). Interpetasi hibrida citra satelit resolusi spasial menengah untuk kajian densifikasi bangunan daerah perkotaan di daerah perkotaan Yogyakarta. Universitas Gajah Mada.

Wahyudi, A., Liu, Y., \& Corcoran, J. (2018). Combining landsat and landscape metrics to analyse large-scale urban land cover change: a case study in the Jakarta Metropolitan Area. Journal of Spatial Science, 64(3), 515-534. doi:10.1080/14498596.2018.1443849. 